\title{
Relative Importance of Public Debts and Money Growth on Inflation in Nigeria
}

\author{
Olusola Joel Oyeleke ${ }^{1} \&$ Monica Adele Orisadare ${ }^{2}$ \\ ${ }^{1}$ Economics Department, Emmanuel Alayande College of Education, Oyo, Oyo State, Nigeria \\ ${ }^{2}$ Economics Department, Obafemi Awolowo University, Ile-Ife, Osun State, Nigeria \\ Correspondence: Olusola Joel Oyeleke, Economics Department, Emmanuel Alayande College of Education, Oyo, \\ Oyo State, Nigeria. Tel: 234-803-565-4069. E-mail: oyelekeolusola1 @ gmail.com
}

Received: April 23, 2018

Accepted: June 6, 2018

Online Published: June 15, 2018

doi:10.5539/ijef.v10n7p99

URL: https://doi.org/10.5539/ijef.v10n7p99

\begin{abstract}
This paper investigates the relative importance of public debts and money growth on inflation in Nigeria from 1980 to 2015. Annual secondary data collected from World Development Indicators were used for the analysis. After examining the behaviour of the time series, Unrestricted Vector Autoregressive (VAR) technique of estimation is employed with a view to determining whether inflation is a monetary or fiscal phenomenon in Nigeria. The results show that, both in the short and long run, public debts accounts for a sizeable percentage in the variation of inflation rather than growth in monetary supply, making inflation a fiscal phenomenon in Nigeria. We therefore recommend that the attainment of fiscal solvency would be more effective in achieving price stability in Nigeria.
\end{abstract}

Keywords: public debts, money, inflation, regression

\section{Introduction}

The issue of perpetual budget deficits and high inflation plaguing the economy of Nigeria, over the past three decades, has called for a renewed interest in investigating the relationship between the two variables. The merits that budget deficits could have in stimulating economic growth of Nigeria- a developing nation, notwithstanding, evidence from empirical literature have emerged that large and perpetual fiscal deficits have been accompanied by high exchange rates and large public debts emanated from huge debts services (see Osinubi \& Olaleru, 2006; Wosowei, 2013). However, the monetary authority in Nigeria, the Central Bank of Nigeria (CBN), has consistently and substantially relied on the adjustments of monetary variables such as monetary base and exchange rates to achieve price stability which has eluded the country, while fiscal deficits has been considered unimportant.

Data from Central Bank of Nigeria (2015), for instance, showed that the total money supply in 1981 was 14.47 billion naira, the inflation rate was 1 per cent, while the deficits stood at 3.90 billion naira. In 1986, total money stock was 20.11 billion naira, inflation rate increased to 13.7 per cent and the deficit jumped to 8.25 billion naira. From the figure, within the period, the money supply had increased by $28 \%$, inflation rose by over $13 \%$, while budget deficits had risen by 53\%. Similarly, in 2012, the total money supply to the economy was $13,895.39$ trillion naira, while the inflation rate was 12 per cent and budget deficit was -975.68 billion naira. Also, in 2014, the money supply was 17,680.52 trillion naira, inflation rate dropped to 8 per cent and budget deficit slightly increased to 978.43 billion naira. In the same period, the percentage increase in money supply was $127 \%$, there was $1.5 \%$ reduction in price level despite the upsurge in money supply to the economy, while budget deficit rose by $0.01 \%$.

In macroeconomic literature, there are two possible channels through which perpetual and high fiscal deficits generate high inflation rates in an economy that are not directly related to the growth of money supply. First, perpetual fiscal deficits result to inflation as a government faced with high and persistent fiscal deficits find money creation (seignorage) a solution to financing fiscal deficits, thereby making inflation a monetary phenomenon (Javid \& Arif ,2014). Second is the postulations of fiscal theory of price level (FTPL). Fiscal deficits lead to inflation even when central bank does not monetize the public debts. As the government strives to achieve intertemporal budget constraint, the price level must increase to lessen the effect of public real debts 
accumulated, making inflation a fiscal phenomenon (Canzoneri, Cumby, \& Diba, 2001; Pitttila, 2000; and Lin \& $\mathrm{Chu}, 2013)$. Government intertemporal budget constraint presents that the current value of government nominal debt net of interest payment is equal to the present discounted value of future government total revenues.

In Nigeria, the Central Bank of Nigeria (CBN) has not been offsetting budget deficits with money creation (seignorage), yet, there have been growing concerns in the literature, that persistent fiscal deficits may also have accounted for high inflation rates aside of growth in money supply and exchange rates depreciation. This implies that the wealth effect of government bonds and treasury bills could still jeopardize the objective of price stability of CBN, regardless of the monetary authority's commitment to low inflation rates in the economy.

In most of the developed economies, empirical studies have documented that the roles of monetary authorities have not been conflicting with roles of fiscal authorities. The development does not make inflation to be associated with fiscal deficits as central banks have been independent of fiscal authorities. Invariably, central banks are more independent in those economies compared with what obtains in most of the transition economies, like Nigeria, where the president's voice is heard on exchange rates determination. Although the Central Bank of Nigeria's primary function of maintaining price stability is sacrosanct, however, recent experience of monetary authority in the country have tended to blur the separation of its policies from fiscal authority's.

Although economists' views about the determination of inflation may be different, a consensus interest, however, holds about detrimental effects of the persistent increase in the variable on developing economy such as Nigeria. High inflation rates in Nigeria, for instance, distorts relative prices and inhibits good standard of living. It erodes the trust in macroeconomic policies of the government, encourages unproductive activities such as smuggling, tax evasion, internet scamming, kidnapping and other financial and social crimes aimed at hedging against inflation in the economy. The study, therefore, investigates whether QTM or FTLP is plausible in explaining inflation variability in Nigeria. In particular, the aim is to ascertain whether public debts or money growth is responsible for high inflation phenomenon.

\section{Empirical Literature}

Based on different theories, several authors have investigated the determination of inflation in various economies. Lin and Chu (2013) examined the deficit-inflation relationship in 91 countries from 1960 to 2006, using the dynamic panel quartile regression (DPQR) model under the autoregressive distributional lag (ARDL). The DPQR model estimated the impact of deficits on inflation at various inflation levels and allowed for a dynamic adjustment with the ARDL specification. The empirical results showed that the fiscal deficit had a strong impact on inflation in high-inflation episodes, implying that fiscal consolidation would be more effective in price stabilization. Similarly, Cata o and Terrones (2005) tested the postulation that persistent fiscal deficits were inflationary in 107 countries over 1960-2001. Unlike previous studies, they modeled inflation as non-linear relation with fiscal deficits through the inflation tax base, using panel techniques that explicitly distinguished between short- and long-run effects of fiscal deficits. Their results showed a strong positive association between deficits and inflation among high-inflation and developing country groups, but not among low-inflation economies. Similarly, Pirttila (2000) investigated fiscal explanation for inflation in transition economies that included Bulgaria, Romania and Russia, using Vector autoregressive methodology. The author found mixed results that fiscal deficit partly increased inflation in Bulgaria, while the opposite held for Romania and Russia.

Askoy and Melina (2011) provided evidence that fluctuations in certain fiscal variables of US contained valuable information to predict fluctuations in output and prices. The distinction between federal and state-local fiscal indicators yielded useful insights and helped the authors to define a new set of stylized facts for U.S. macroeconomic conditions. The results showed that the federal, state and local expenditures helped predict U.S. inflation. Using quarterly data for the period 1990:1-2008:4 in Nigeria, Omanukwue (2010) examined the modern quantity theory of money. The study used the Engle-Granger two -stage test for cointegration to examine the long-run relationship between money, prices, output and interest rate. The author found evidence of a long-run relationship in line with the quantity theory of money. Against the backdrop of mixed results in the literature, Pekarski (2011) investigated the relationship between budget deficits and inflation in high inflation economies. The results showed dramatic shifts between regimes of moderately high and extremely high (hyper-) inflation often occur without visible deterioration in public finance or abrupt shifts in fiscal or monetary policies.

Zonuzi, Pourvaladi, and Faraji (2011), re-investigate the deficit-inflation nexus in the Iranian economy. Structural break test and Bounds test were used to investigate the long-run relationship between budget deficit and inflation. The findings showed strong evidence of a positive relationship between budget deficit and inflation in Iran. Habibullah, Schoeman, and Baharom (2011) investigated the long-run relationship between budget deficit and inflation in thirteen Asian developing countries between 1950 and 1999, using the 
error-correction model. The results indicated that budget deficits were inflationary in Asian developing countries, which was in consonance with the results of Lin and Chu (2013) and Cata o and Terrones (2005).

It is imperative to note that some authors have investigated either the effect of inflation on economic growth of Nigeria or the relationship between the two variables. Nigeria, Ezeabasili et al. (2012) re-examined the deficit-inflation nexus, using data over 1970-2006. The authors adopted a cointegration technique and structural analysis. The study did not find any strong evidence linking past levels of fiscal deficits, but rather a positive long run relationship between money supply and inflation in the economy. The result therefore inflation was a monetary phenomenon in Nigeria. Dockery et al. (2012) investigated the long term relationship between fiscal deficits and inflation for Nigeria. Their empirical results showed that there was an evidence of a positive long-run relationship between money supply and inflation. Ozurumba (2012) examined the causal relationship between inflation and fiscal deficits in Nigeria, covering the period 1970-2009. Using autoregressive distributed lag (ARDL) model, and granger-causality tests, the results showed that fiscal deficit caused inflation and no feedback mechanism was observed. However, the ARDL results confirmed a significant negative relationship between growth in fiscal deficit and inflation. Dockery et al. (2012) investigated the long term relationship between fiscal deficits and inflation for Nigeria. Their empirical results showed that there was a positive but insignificant relationship between fiscal deficits and inflation. Keho (2016) employed bound testing coinegration technique to examine budget deficits, money supply and the price level in West African Monetary Zone. The author found that the prise level were positively related in Niger and Togo but negatively correlated in Benin and Senegal.

From empirical literature reviewed, especially on Nigeria, apart from mixed evidence generated from among the studies, attempt have not been made to use analytical model of government intertemporal budget constraint as emphasises by fiscal theory of price level (FTPL) in investigating the relative importance of wealth effect and money growth on inflation in Nigeria. Hence, this study attempted to fill this gap.

\section{Data and Model Specification}

Annual time series data which included total public debts (domestic plus foreign), monetary base (M1), real GDP and consumer price index (CPI) (proxied for inflation) were employed. The data were sourced from World Development Index (WDI), 2016. In our analysis of the inflation determination, model specification follows Javid and Arif (2014). The model explains that the value of public debts must be equal to the present discounted value of future government primary surplus. The equation is given as;

$$
B_{t}=\left(T_{t}-G_{t}\right)+\left(M_{t+1}-M_{t}\right)+\frac{B_{t+1}}{\left(1+i_{t}\right)}
$$

$B_{t}$ is public debt at the beginning of the period and $M_{t}$ is base money. $T_{t}-G_{t}$ is the primary surplus during the period $\mathrm{t}$ and $i_{t}$ is the interest payment for the period t. Equation (1) implies that the value of current government debts have to be paid off, monetised or financed through issuance of bonds or treasury bills. To put the size of the economy into perspective, the budget constraint however takes liabilities and surpluses as a ratio of nominal GDP. It should be noted that the liability of government contains the money supply to the economy and the values of bonds or treasusry issued. Therefore, all the variables are presented as ratio of nominal GDP. Hence, the equation below:

$$
\frac{M_{t}+B_{t}}{P_{t} y_{t}}=\left[\frac{T_{t+1}-G_{t+1}}{P_{t} y_{t}}+\left(\frac{M_{t+1}}{P_{t} y_{t}}\right)\left(\frac{i_{t}}{1+i_{t}}\right)\right]+\left(\frac{y_{t+1 / y_{t}}}{\left(1+i_{t}\right)\left(P_{t} / P_{t+1}\right)}\right)\left(\frac{M_{t+1}+B_{t+1}}{P_{t+1} y_{t+1}}\right)
$$

Equation (2) states that the ratio of the total government liabilities to GDP must be equal to the primary surplus as a ratio of GDP, plus the discounted values of next period government liabilities as a ratio of GDP. The discounted factor is the ratio of real growth in GDP to the real interest rate. Simplifying equation (2) further, for convenience, let

$$
\begin{gathered}
\frac{\mathrm{M}_{\mathrm{t}}+\mathrm{B}_{\mathrm{t}}}{\mathrm{P}_{\mathrm{t}} \mathrm{y}_{\mathrm{t}}}=\mathrm{w}_{\mathrm{t}},\left[\frac{\mathrm{T}_{\mathrm{t}}-\mathrm{G}_{\mathrm{t}}}{\mathrm{P}_{\mathrm{t}} \mathrm{y}_{\mathrm{t}}}+\left(\frac{\mathrm{M}_{\mathrm{t}+1}}{\mathrm{P}_{\mathrm{t}} \mathrm{y}_{\mathrm{t}}}\right)\left(\frac{\mathrm{i}_{\mathrm{t}}}{1+\mathrm{i}_{\mathrm{t}}}\right)\right]=\mathrm{s}_{\mathrm{t}} \text { and } \\
\left(\frac{\mathrm{y}_{\mathrm{t}+1 / \mathrm{y}_{\mathrm{t}}}}{\left(1+\mathrm{i}_{\mathrm{t}}\right)\left(\mathrm{P}_{\mathrm{t}} / \mathrm{P}_{\mathrm{t}+1}\right)}\right)\left(\frac{\mathrm{M}_{\mathrm{t}+1}+\mathrm{B}_{\mathrm{t}+1}}{\mathrm{P}_{\mathrm{t}+1} \mathrm{y}_{\mathrm{t}+1}}\right)=\phi_{\mathrm{t}} \mathrm{w}_{\mathrm{t}+1}
\end{gathered}
$$

where $w_{t}$ is liabilities-to-GDP, $s_{t}$ represents surpluses-to-GDP ratio and $\phi_{t}$ is discount factor. It should be noted that in Canzoneri et al. (2001), $s_{t}$ includes seignorage which, however, in our own study, will include revenues generated from oil exports. Then the equation that follows is presented as:

$$
w_{t}=s_{t}+\phi_{t} w_{t+1}
$$


Iterating equation (3) one period ahead from the current period t and taking the expectations conditional on information available in period t. The present value government intertemporal budget constraint becomes:

$$
w_{t}=s_{t}+E_{t} \sum_{i=t+1}^{\infty}\left(\prod_{k=t}^{i-1} \phi_{k}\right) s_{t}+\lim _{n \rightarrow \infty} E_{t}\left(\prod_{k=t}^{t-1} \phi_{k}\right) w_{t+1}=0
$$

FTPL treats equation (4) as equilibrium that must be satisfied, should solvency hold. According to Javid and Arif (2014), if primary surpluses are determined by an arbitrary process unrelated to primary debts, then nominal income and/or discount factor must jump in equilibrium to satisfy (4), hence the policy regime that prevails is called non-Ricardian or fiscal dominant regime. Conversely, if primary surpluses are determined in such a way that equation (4) is satisfied, irrespective of the value of nominal income and discount factor determined elsewhere in the model, then the prevailing policy regime is called the Ricardian or monetary dominant regime. Now, allowing for modification of equation (4) to suit our study as this is not clearly done in Cansoneri, et al (2001), the so-called no Ponzi game (NPG) condition has to be invoked as in Hamilton and Flavin (1986) and Hakkio and Rush, (1991) i.e. the term;

$$
\lim _{n \rightarrow \infty} E_{t}\left(\prod_{k=t}^{t-1} \phi_{k}\right) w_{t+1}=0
$$

Equation (5) is also called transversality condition, which states that the debt stock, when measured in present value terms, vanishes in the limit. By definition, it excludes Ponzi financing, i.e. the government is not 'bubble'-financing its expenditure by issuing new debt to finance the deficit. In another word, this condition states that the present value of the government's debt in the indefinite future converges to zero. This is equivalent to saying that the deficit is sustainable if and only if the stock of real debt held by the government is expected to grow not faster than the average real rate of interest, which is viewed as a proxy for the growth rate of the economy. However, for this to happen, real debt must grow more slowly than the real interest rate, which is the growth rate of the discounting factor (Jibao, Schoeman, \& Naraidoo, 2012). Therefore, equation (4) is reduced to;

$$
w_{t}=s_{t}+E_{t} \sum_{i=t+1}^{\infty}\left(\prod_{k=t}^{i-1} \phi_{k}\right) s_{i}
$$

Equation (6) is called intertemporal government budget constraint. Assuming that the NPG condition is satisfied, it is easy to see that the government debt, at any point in time, must be equal to the present value of its expected future primary surpluses. Hence, econometric model of equation (6) becomes:

$$
S_{t}=\propto+\beta_{t} w_{t}+\varepsilon_{t}
$$

Where $\beta_{t}$ is the parameter and $\varepsilon_{t}$ is the random variable. The main argument as noted by Lima et al. (2012) is whether the price level adjusts to expected future surpluses or the path of surpluses adjusts in response to the price level.

\section{Estimation Techniques}

The estimation techniques employed in examining the relative importance of wealth effect of public debts and monetary supply on inflation in Nigeria involved testing for the dynamic effect between public debts, monetary growth and inflation, therefore, Vector Autoregressive (VAR) method was employed. Initially, two forms of unit root tests were carried out, using notable techniques of Augmented Dickey and Fuller (1979) and Phililps and Perron (1988). Another step was taken which involved the use of Johansen cointegration test to determine the long run relationship among our series. Equation (7) was restructured in an unrestricted Vector Auto Regressive (VAR) model. In the VAR model, more attention was paid to forecast error variance decomposition and impulse response functions to determine whether wealth effect of public debts or money supply explained inflation variability in Nigeria during the period under reviewed. Thus, equation (7) was stated in VAR model using the first difference of its variables. Also, all the variables except inflation rates were in log form. Hence, the model:

$$
Y_{t}=\beta_{10}-\beta_{12} X_{t}+\gamma_{11} Y_{t-1}+\gamma_{12} X_{t-1}+\mu_{y t}
$$

Since our VAR models contain four variables, therefore, we specify equation (8) as follows:

$$
Y_{t}=\beta_{10}-\beta_{12} \sum_{t=0}^{p} X_{t}+\gamma_{11} Y_{t-1}+\gamma_{12} \sum_{i=1}^{q} X_{t-i}+\mu_{t}
$$

Where $Y_{t}$ is vector of endogenous variables and $X_{t}$ is a vector of explanatory variables in the system and $\mu_{t}$ the vector of reduced form residuals. Therefore, the reduced form of the VAR model can be written as:

$$
Y_{t}=A(L) Y_{t-1}+\mu_{t}
$$

To test for the existence of wealth effect of fiscal deficit in Nigeria, following the order of specification suggested in Javid and Arif (2014), this VAR ordering was followed: (TAD) $\rightarrow$ (M1) $\rightarrow$ (RGDP) $\rightarrow$ (INF). Both, impulse response functions and the variance error decompositions for inflation were computed. Forecast error variance 
decompositions would separate the variability in inflation rates into component shocks to the VAR that would supply information about the relative importance of each random innovation in affecting inflation rates. If the forecast error is explained by shocks to total public debts, it is argued that changes in inflation could be determined by the wealth effects of total public debts, then inflation was a fiscal phenomenon in Nigeria. In contrast, if the forecast error is explained by shocks to money supply, the result would be interpreted to mean; inflation is a monetary phenomenon in Nigeria.

\section{Results and Discussion}

From table 1, the results of ADF test showed that total public debts, monetary base, real GDP were first difference variables at $1 \%$ and $5 \%$ level of significance, with the exception of CPI which had stationary at level. However, the results of PP showed that all our variables were first difference variables at $1 \%$ and $5 \%$ levels of significance.

Table 1. Results of unit root

\begin{tabular}{lcccc}
\hline Variable & \multicolumn{2}{c}{ ADF } & PP \\
\cline { 2 - 5 } & Level & First Difference & Level & First Difference \\
\hline CPI & $-2.7407^{* * *}$ & & -2.6140 & $-8.5840^{*}$ \\
LM1 & -2.3555 & $-3.9366^{*}$ & -2.1141 & $-5.6818^{*}$ \\
LRGDP & 1.2445 & $-.3 .3129^{*}$ & 4.4709 & $3.0462^{* *}$ \\
LTAD & 0.1492 & $-3.0350^{* *}$ & 0.9066 & $-6.6316^{*}$ \\
\hline
\end{tabular}

Source: Author's Computation (2018).

indicating that all our variables were integrated of the same order. We therefore concluded that all our four variables were first difference series, hence VAR method of analysis was applicable. On the lag length selection order, we considered the suggestions of Pesaran and Shin (2001) that two (2) lag length order for annual data should be selected to preserve the degree of freedom, hence two lag length was chosen in this study.

\subsection{Cointegration}

Table 2 presented the Johansen cointegration results. It was revealed that no long run relationship existed among our variables, given Trace and Maximum Engen statistics based on 5\% significant level. Therefore, the hypothesis of no cointegrating among the variables was not rejected, using Mackinnon-Haug-Michel (1999) p-values.

Table 2. Results of Johansen maximum likelihood cointegration test

\begin{tabular}{ccccc}
\hline Trace test & 5\% Ccritical Value & Max-Engen Stat. & 5\% Critical Value & Hypotheses \\
\hline 42.459 & 47.85613 & 17.326 & 27.58434 & $\mathrm{r}=0$ \\
25.133 & 29.79707 & 11.563 & 21.13162 & $\mathrm{r} \leq 1$ \\
13.570 & 15.49471 & 9.080 & 14.26460 & $\mathrm{r} \leq 2$ \\
3.490 & 3.841466 & 3.490 & 3.841466 & $\mathrm{r} \leq 3$ \\
\hline
\end{tabular}

Source: Author's Computation, (2018).

* denoted rejection of the hypothesis at the 5\% level of significance based on MacKinnon-Haug-Michels (1999) p-values.

Having established no long run relationship among the variables and the maximum lag length that could be included was two, equation (10) was estimated, using Unrestricted VAR technique of estimation. Among the several procedures involved in VAR technique, two procedures were engaged; forecast error variance decomposition and impulse response functions. The first method separates the variations in the variable of interest into component shocks to the VAR, thereby providing information about the relative importance of each random innovation affecting the variable, while the second shows the direction of relationship over a given time period.

The result of forecast error variance decomposition is presented in Table 3. The result showed that, in the short run, i.e. 1st, 2nd and 3rd year respectively, one standard deviation innovation to total debts (LTAD) produced (4.134), (3.094) and (3.078) percent of variation in inflation, while in the long run, for instance, 8th,, 9th and 10th year, (9.202), (9.372) and (9.399) percent of the variations in inflation were due to one standard deviation shock to total debts in Nigeria. For the same time horizon, however, i.e. in the short run, 1st, 2nd and 3rd year, one standard deviation shock to monetary base (LM1) influenced inflation to vary by $(0.026),(0.203)$ and $(0.991)$ 
percent, while in the long run, i.e. 8th, 9th and 10th year, one standard deviation innovation to (LM1) made inflation to vary by (1.915), (1.915) and (1.976) percent respectively. Comparatively, the proportion of variation in inflation explained by shocks to total debts growth outweighed that of monetary base growth, making inflation a fiscal phenomenon in Nigeria. It could therefore, be summarised that the debts finances in Nigeria had been correlated with inflation variability in the economy. Put differently, the wealth effect of debts financing impacted positively on inflation variability in Nigeria, a development which could be understood that the government intertemporal budget constraint had been satisfied with the recourse to changes in price level to lessen the effect of real debts on the economy, suggesting that inflation is a fiscal phenomenon in Nigeria.

Table 3. Result of forecast error variance decomposition of inflation (INF)

\begin{tabular}{cccccc}
\hline Period & S.E. & LTAD & LM1 & LRGDP & INF \\
\hline 1 & 16.26952 & 4.133885 & 0.025648 & 2.712784 & 93.12768 \\
2 & 19.86256 & 3.094051 & 0.202569 & 1.821961 & 94.88142 \\
3 & 20.41722 & 3.078099 & 0.990701 & 1.975211 & 93.95599 \\
4 & 20.59237 & 3.792473 & 1.722824 & 2.119883 & 92.36482 \\
5 & 20.83091 & 5.466539 & 1.966720 & 2.088043 & 90.47870 \\
6 & 21.05300 & 7.352101 & 1.959957 & 2.061580 & 88.62636 \\
7 & 21.21085 & 8.630339 & 1.930972 & 2.110746 & 87.32794 \\
8 & 21.30125 & 9.201819 & 1.915220 & 2.208149 & 86.67481 \\
9 & 21.34564 & 9.372028 & 1.914938 & 2.317279 & 86.39575 \\
10 & 21.37350 & 9.398777 & 1.975915 & 2.419914 & 86.20539 \\
\hline
\end{tabular}

Source: Author's Computation, (2018).

By implication, the incidence of wealth effect of debts financing passed through to prices by increasing inflation variability in Nigeria as predicted by fiscal theory of price level. This could be an indication that the federal government debts issued through treasury bills, certificates and bonds are majorly held by commercial banks and individuals using the interest yields on bonds to create more money in circulation which passed through to inflation. This showed that the government of Nigeria has not been financing deficits with seigniorage, but charging inflation tax that could reduce the real value of debts to have government intertemporal budget constraint satisfied. This result has corroborated the findings of Jalil, Tariq, and Bibi (2014) for Pakistani economy which discovered that debts financing in Pakistan had been passing through to increase in price level, which affirmed the plausibility of fiscal theory of price level in Pakistan. Also, the study confirmed the assertion of Grauwe and Polan (2005) that money does not matter in an economy which does not experience hyperinflation. Again, the result tilted towards the findings of Omanukwue (2010) on Nigerian economy which tested the plausibility of quantity theory of money and found that the relationship between money and inflation was weak.

Similarly, this result was in consonance with the study of Salami and Kelikume (2013) on Nigeria. The authors found that the quantity theory relationship between money and price level did not hold, thereby disproving that inflation is always and everywhere a monetary phenomenon as claimed by Milton Freidman (1968). The result also confirmed the findings of Fisher, Sahay and Vegh (2002) which reported that fiscal deficits derived inflation in developing economies. Furthermore, this was not at variant with Tekin-Koru and Ozmen (2003) who found that prices were not determined by monetary growth, but only adjust to the increase in the private sector nominal wealth caused by the deficits that were financed with bonds. The impulse response functions revealed that inflation responded to one standard deviation shocks in total debts in more conspicuous manner than in monetary base, which showed that total government debts financing explained variability in inflation in Nigeria better than monetary base. This is contrary to the view of quantity theory of money.

\section{Summary and Conclusion}

The study examined the relative importance of wealth effect of public debts and money growth on inflation by applying forecast error decomposition of unrestricted VAR to total debts, monetary base, real GDP and inflation series between 1981 and 2015 in Nigeria. The results of the study showed that innovations to total debts explained, on average, about $10 \%$ in total variation to inflation in Nigeria, while monetary base accounted for, on average, about $2 \%$ in total variation in inflation during the period covered. The findings indicate that, in Nigeria, inflation is a fiscal phenomenon as against monetary phenomenon, thereby upholding claim of the fiscal theory of price level. The implication is that inflation is not always and everywhere a monetary phenomenon contrary to 
the submission of Quantity of theory of money. The study therefore recommends that government should strive to generate more revenues, especially through diversification of the economy to agricultural based export country, create more tax base and curtail the activities of smugglers to generate more funds, instead of borrowing to finance the economy.

\section{References}

Askoy, Y., \& Melina, G. (2011). U.S. fiscal indicators, inflation and output North American Journal of Economics and Finance, 22, 221-236. https://doi.org/10.1016/j.najef.2011.02.001

Canzoneri, M. B., Cumby, R., \& Diba, B. T. (2001). Is the Price Level Determined by the Needs of Fiscal Solvency? American Economic Review, 91, 1221-1238. https://doi.org/10.1257/aer.91.5.1221

Catão, L. A. V., \& Terrons, M. (2005). Fiscal Deficit and Inflation. Journal of Monetary Economics, 52, 529-554. https://doi.org/10.1016/j.jmoneco.2004.06.003

Dockery, E., Ezeabasili V. N., \& Herbert, W. E. (2012). On the Relationship between Fiscal Deficits and Inflation: Econometric Evidence for Nigeria. Economics and Finance Review, 2(7), 17-30.

Ezeabasili1, V. N., Mojekwu, J. N., \& Herbert. W. E. (2012). An Empirical Analysis of Fiscal Deficits and Inflation in Nigeria. International Business and Management, 4(1), 105-120.

Fischer, S., Sahay, R., \& Vegh, C. (1996). Modern Hyper-and High inflation Journal of Economic Literature, 40, 837-880. https://doi.org/10.1257/jel.40.3.837

Friedman, M. (1968). The role of monetary policy. The American Economic Review, 58(1), 1-17.

Grauwe, P. D., \& Polan, M. (2005). Is Inflation Always and Everywhere a Monetary Phenomenon? The Scandinavian Journal of Economics, 107(2), 239-259. https://doi.org/10.1111/j.1467-9442.2005.00406.x

Habibullah, M. S., Cheah, C., \& Baharom, A. H. (2011). Budget Deficits and Inflation in Thirteen Asian Developing Countries. International Journal of Business and Social Science, 2(9), 192-204.

Jalil, A., Tariq, R., \& Bibi, N. (2014). Fiscal Deficit and Inflation: New Evidences from Pakistan Using A $\begin{array}{lllll}\text { Bounds Testing } & \text { Approach. }\end{array}$ https://doi.org/10.1016/j.econmod.2013.10.029

Javid, Y. A., \& Arif, U. (2014). Fiscal and Monetary Regime Identification for Price Stability in Case of Pakistan Economy. Journal of Economic Cooperation and Development, 35(3), 43-70.

Jibao, S. S., Schoeman, N. J., \& Naraidoo. (2012). Fiscal Regime Changes and The Sustainability of Fiscal Imbalance in South Africa: A Smooth Transition Error-Correction Approach. South Africa Journal of Economics, 15(2), 112-127. https://doi.org/10.4102/sajems.v15i2.179

Keho, Y. (2016) Budget Deficits, Money Supply and Price Level in West Africa. Journal of Economic and Financial Studies, 4(5), 1-8. https://doi.org/10.18533/jefs.v4i05.209

Lin, H. Y., \& Chu, H. P. (2013). Are Fiscal Deficit Inflationary? Journal of International Money and Finance, 32, 214-233. https://doi.org/10.1016/j.jimonfin.2012.04.006

Osinubi, T. S., \& Olaleru, O. E. (2006). Budget Deficits, External Debt and Economic Growth in Nigeria. Applied Econometrics and International Development, 6(3), 159-185.

Pekarski, S. (2011). Budget Deficits and Inflation Feedback. Structural Changes and Economic Dynamics, 22, 1-11. https://doi.org/10.1016/j.strueco.2010.09.002

Pesaran, M. H., Shin, Y., \& Smith, R. J. (2001). Bounds testing approaches to the analysis of level relationships. Journal of Applied Econometrics, 16(3), 289-326. https://doi.org/10.1002/jae.616

Phillips, P. C. B., \& Perron, P. (1988). Testing for a Unit Root in a Time Series Regression. Biometrika, 75(2), 335-346. https://doi.org/10.1093/biomet/75.2.335

Pitttila, T. K. J. (2000). Fiscal Explanations for Inflation: Any Evidence for Transition Economies? BOFIT Discussion Paper 11.

Salami, D., \& Kelikume, I. (2013). Is Inflation always and everywhere a Monetary Phenomenon? The case of Nigeria. The International Journal of Business and Finance Research, 7(2), 105-114.

Tekin-Koru, A., \& Ozmen, E. (2003). Budget deficits, money growth and inflation: The Turkish Evidence. Applied Economics, 35(5), 591-596. https://doi.org/10.1080/0003684022000025440

Wosowei, E. (2013). Fiscal Deficit and Macroeconomic Aggregates in Nigeria. Kuwait Chapter of Arabian 
Journal of Business and Management Review, 2(9), 72-82. https://doi.org/10.12816/0001235

Zonuzi, J. M., Pourvaladi, M. S. H., \& Faraji, N. (2011). The Relationship between Budgets Deficit and Inflation in Iran. Iranian Economic Review, 15(28), 118-133.

\section{Appendix A}

Variance decomposition of VAR among LTAD, LM1, LRGDP and INF

\begin{tabular}{|c|c|c|c|c|c|}
\hline \multicolumn{6}{|c|}{ Variance Decomposition of LTAD: } \\
\hline Period & S.E. & LTAD & LM1 & LRGDP & INF \\
\hline 1 & 698.3583 & 100.0000 & 0.000000 & 0.000000 & 0.000000 \\
\hline 2 & 1170.381 & 99.59538 & 0.001222 & 0.196352 & 0.207047 \\
\hline 3 & 1470.084 & 98.78296 & 0.096453 & 0.985490 & 0.135101 \\
\hline 4 & 1631.619 & 96.90913 & 0.232468 & 2.320148 & 0.538256 \\
\hline 5 & 1707.573 & 94.55612 & 0.219928 & 3.921248 & 1.302708 \\
\hline 6 & 1744.478 & 92.18303 & 0.459695 & 5.504643 & 1.852636 \\
\hline 7 & 1775.463 & 89.30697 & 1.820527 & 6.864599 & 2.007902 \\
\hline 8 & 1817.775 & 85.30366 & 4.840800 & 7.909266 & 1.946275 \\
\hline 9 & 1876.239 & 80.24002 & 9.272908 & 8.660148 & 1.826927 \\
\hline 10 & 1949.763 & 74.72908 & 14.38025 & 9.198072 & 1.692598 \\
\hline \multicolumn{6}{|c|}{ Variance Decomposition of LM1: } \\
\hline Period & S.E. & LTAD & LM1 & LRGDP & INF \\
\hline 1 & 1079160. & 0.471991 & 99.52801 & 0.000000 & 0.000000 \\
\hline 2 & 1418590. & 5.611847 & 94.22224 & 0.034260 & 0.131651 \\
\hline 3 & 1583158. & 8.719628 & 90.39132 & 0.078547 & 0.810505 \\
\hline 4 & 1661902. & 9.235501 & 89.35847 & 0.192207 & 1.213824 \\
\hline 5 & 1697472. & 8.871539 & 89.52907 & 0.339335 & 1.260060 \\
\hline 6 & 1717523. & 9.127680 & 89.20203 & 0.433453 & 1.236839 \\
\hline 7 & 1734041. & 10.26208 & 88.06316 & 0.456428 & 1.218333 \\
\hline 8 & 1748717. & 11.64471 & 86.67591 & 0.449819 & 1.229555 \\
\hline 9 & 1759935. & 12.68685 & 85.57455 & 0.450030 & 1.288576 \\
\hline 10 & 1766821. & 13.24541 & 84.92114 & 0.466843 & 1.366614 \\
\hline \multicolumn{6}{|c|}{ Variance Decomposition of LRGDP: } \\
\hline Period & S.E. & LTAD & LM1 & LRGDP & INF \\
\hline 1 & 877.0391 & 2.285673 & 21.86494 & 75.84939 & 0.000000 \\
\hline 2 & 1533.489 & 2.249132 & 43.13893 & 54.29042 & 0.321520 \\
\hline 3 & 2237.314 & 3.078572 & 57.11566 & 39.34098 & 0.464782 \\
\hline 4 & 2955.571 & 4.564037 & 64.37550 & 30.70055 & 0.359920 \\
\hline 5 & 3666.754 & 6.473883 & 67.68936 & 25.60166 & 0.235099 \\
\hline 6 & 4366.848 & 8.563809 & 68.83880 & 22.40651 & 0.190888 \\
\hline 7 & 5058.362 & 10.63125 & 68.84775 & 20.30567 & 0.215324 \\
\hline 8 & 5745.605 & 12.53715 & 68.30497 & 18.88546 & 0.272421 \\
\hline 9 & 6433.525 & 14.20165 & 67.54756 & 17.91309 & 0.337702 \\
\hline 10 & 7127.490 & 15.59260 & 66.76427 & 17.24359 & 0.399538 \\
\hline \multicolumn{6}{|c|}{ Variance Decomposition of INF: } \\
\hline Period & S.E. & LTAD & LM1 & LRGDP & INF \\
\hline 1 & 16.26952 & 4.133885 & 0.025648 & 2.712784 & 93.12768 \\
\hline 2 & 19.86256 & 3.094051 & 0.202569 & 1.821961 & 94.88142 \\
\hline 3 & 20.41722 & 3.078099 & 0.990701 & 1.975211 & 93.95599 \\
\hline 4 & 20.59237 & 3.792473 & 1.722824 & 2.119883 & 92.36482 \\
\hline 5 & 20.83091 & 5.466539 & 1.966720 & 2.088043 & 90.47870 \\
\hline 6 & 21.05300 & 7.352101 & 1.959957 & 2.061580 & 88.62636 \\
\hline 7 & 21.21085 & 8.630339 & 1.930972 & 2.110746 & 87.32794 \\
\hline 8 & 21.30125 & 9.201819 & 1.915220 & 2.208149 & 86.67481 \\
\hline 9 & 21.34564 & 9.372028 & 1.914938 & 2.317279 & 86.39575 \\
\hline 10 & 21.37350 & 9.398777 & 1.975915 & 2.419914 & 86.20539 \\
\hline \multicolumn{6}{|c|}{ Cholesky Ordering: LTAD LM1 LRGDP INF } \\
\hline
\end{tabular}




\section{Appendix B}
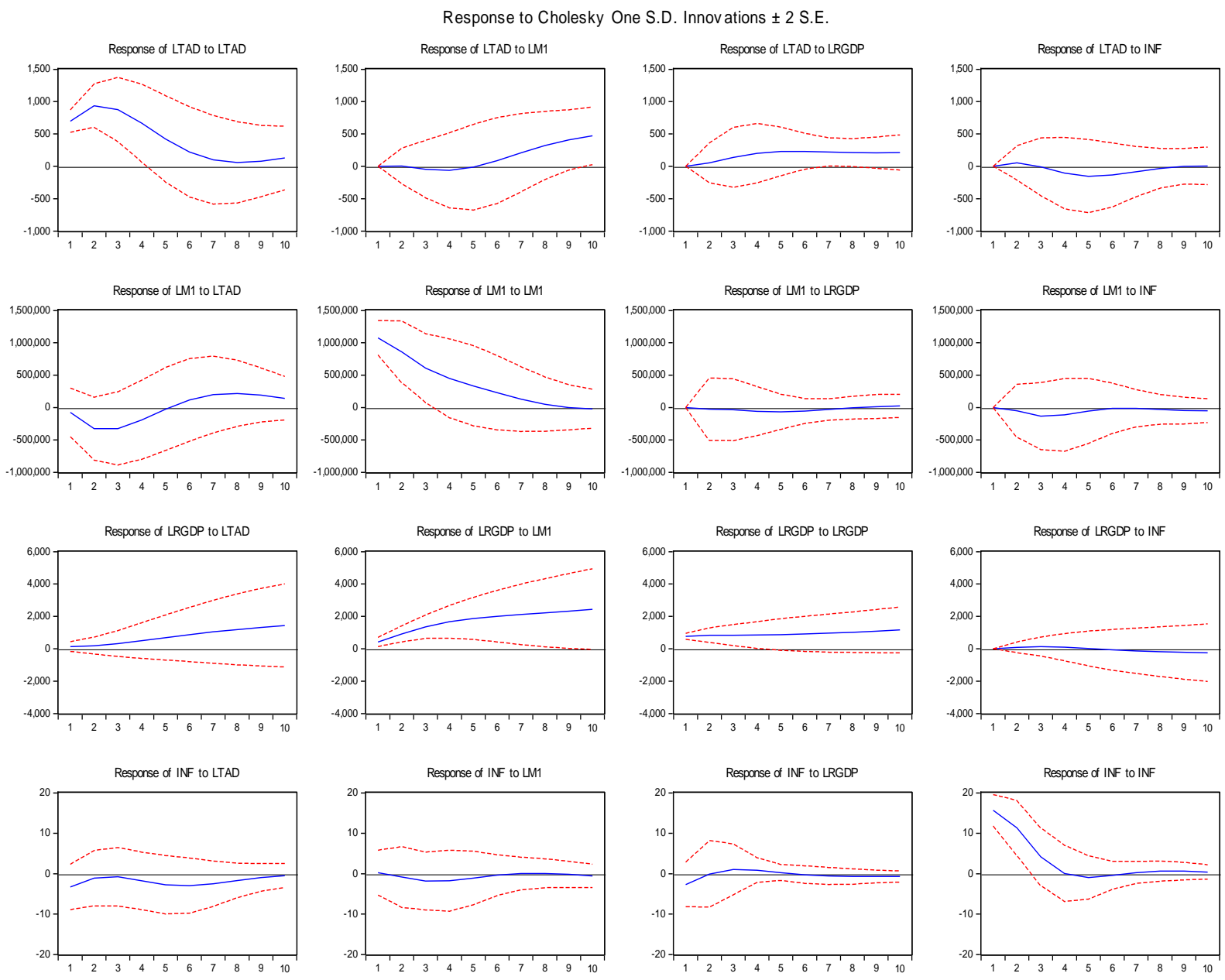

Source: Authors' Computation with eviews9, 2018.

\section{Copyrights}

Copyright for this article is retained by the author(s), with first publication rights granted to the journal.

This is an open-access article distributed under the terms and conditions of the Creative Commons Attribution license (http://creativecommons.org/licenses/by/4.0/). 